\title{
Pemanfaatan Agregat Sungai To Puang Kabupaten Tana Toraja Sebagai Bahan Campuran Beton
}

\author{
Misel Boro Allo*1, Herman Parung*2, Junus Mara' ${ }^{3}$ \\ *1 Mahasiswa Program Studi Teknik Sipil, Universitas Kristen Indonesia Paulus Makassar, \\ Indonesia misel.boroallo@gmail.com \\ *2,3 Dosen Program Studi Teknik Sipil, Universitas Kristen Indonesia Paulus Makassar, Indonesia ${ }^{2}$ \\ hermanparung@gmail.com *2 dan mara.junus@gmail.com *3
}

Corresponding Author: misel.boroallo@gmail.com

\begin{abstract}
Abstrak
Memasuki era New Normal 2021 akibat pandemi Covid-19 membuat semua industri mulai berkembang lagi, khususnya proyek pembangunan infrastruktur. Semua orang berlomba untuk berinisiatif menciptakan beton yang bermutu dan efisien dengan menggunakan material yang ada di sekitarnya. Penelitian ini terfokus pada pemanfaatan agregat Sungai to Puang Kabupaten Tana Toraja sebagai bahan susun campuran beton, untuk mengetahui nilai kuat tekan, nilai kuat tarik belah, nilai kuat lentur, dan nilai modulus elastisitas. Mix design penelitian ini menggunakan metode SNI 7656: 2012. Pada penelitian ini target mutu rencana $f^{\prime} \mathrm{c}=28 \mathrm{MPa}$ dengan nilai faktor air semen (fas) 0,44 . Hasil penelitian ini menunjukkan nilai kuat tekan rata-rata sebesar 30,290 MPa, kuat tarik belah ratarata sebesar 2,902 $\mathrm{MPa}$, kuat lentur rata-rata sebesar 3,376 MPa, dan nilai modulus elastisitas sebesar 20820,747 MPa.
\end{abstract}

Kata kunci: Beton, SNI 7656-2012, Sungai to Puang.

\begin{abstract}
Entering the New Normal 2021 era due to the Covid-19 pandemic, all industries began to develop again, especially infrastructure development projects. Everyone is competing to take the initiative to create quality and efficient concrete by using the materials around it. This research focuses on the utilization of the aggregate of the To Puang River, Tana Toraja Regency as a concrete mix stacking material, to determine the value of compressive strength, split tensile strength value, flexural strength value, and elastic modulus value. The mix design of this study used the SNI 7656:2012 method. In this study, the planned quality target was $f^{\prime} \mathrm{c}=28 \mathrm{MPa}$ with a water-cement factor (fas) of 0.44. The results of this study indicate that the average compressive strength is $30.290 \mathrm{MPa}$, the average split tensile strength is $2.902 \mathrm{MPa}$, the average flexural strength is $3.376 \mathrm{MPa}$, and the modulus of elasticity is $20820.747 \mathrm{MPa}$.
\end{abstract}

Keywords: Concrete, SNI 7656-2012, To Puang River.

\section{PENDAHULUAN}

Penggunaan beton sebagai bahan utama sebuah konstruksi telah lama di aplikasikan dan merupakan yang paling banyak pembangunannya, khususnya pada era New Normal ini, yang membangunkan semua industri khususnya proyek konstruksi. Hal ini dipengaruhi oleh beton yang memiliki sifat mudah di bentuk sesuai dengan keinginan, bisa di desain dengan mutu yang tinggi, bahan yang mudah didapatkan, dan mudah dalam 
perawatannya. Beton termasuk material yang sangat kuat terhadap kuat tekan, tahan terhadap karat, tahan terhadap api. Beton adalah hasil pencampuran antara agregat halus, agregat kasar, semen dan air. Industri beton merupakan sumber daya yang paling banyak penggunaannya di dunia [1].

Dengan perkembangan waktu yang sangat pesat saat ini, semua orang berlomba untuk berinisiatif menciptakan beton yang bermutu dan efisien dengan menggunakan material yang ada di sekitarnya baik merupakan hasil alam yang sering ditemui. Salah satunya dengan menggunakan agregat dari Sungai to Puang Kabupaten Tana Toraja. Agregat alam ataupun agregat buatan adalah agregat yang biasa digunakan dalam pencampuran beton.

Penelitian kali ini berfokus pada agregat yang digunakan berupa agregat alam (batu pecah) yang berasal dari Sungai To Puang Kabupaten Tana Toraja yang berbentuk agregat kasar dan halus. Agregat sangat berpengaruh terhadap kuat tekan beton, maka dari itu akan dilakukan penelitian sifat karakteristik untuk mengetahui syarat dari sebuah pencampuran beton. Adapun sifat karakteristik yang harus diketahui adalah pemeriksaan kadar air, berat jenis, gradasi agregat, berat volume dan modulus kehalusan agregat. Kondisi geografis Negara Indonesia sangat baik, sehingga menyimpan batuan alam yang melimpah di sungai [2]. Masyarakat yang bermukim di dekat aliran sungai memanfaatkan agregat sungai sebagai material beton [3]. Komposisi campuran dari beton akan mempengaruhi nilai kuat tekan yang akan diperoleh [4]. Beton yang di rawat dengan menggunakan metode curing akan menghasilkan kuat tekan yang lebih tinggi dibandingkan beton tanpa perawatan [5]. Beton akan memiliki kekuatan tekan yang lemah jika komposisi campurannya tidak sesuai dengan proporsi dan pengerjaan yang sesuai [6]. Oleh sebab itu, diperlukan perhitungan perencanaan campuran beton yang baik [7] [8].

Berdasarkan latar belakang tersebut, melatarbelakangi penulis untuk melakukan penelitian di laboratorium mengenai Pemanfaatan Agregat Sungai To Puang Kabupaten Tana Toraja Sebagai Bahan Campuran Beton, dikarenakan bahan yang cukup melimpah di daerah tersebut.

\section{Bahan Penyusun Beton}

a. Semen tonasa PCC (Portland composite cement), berdasarkan SNI 15-7064-2004, pasal 3.1 semen Portland komposit adalah bahan pengikat hidrolis dari hasil penggilingan bersama-sama terak semen Portland dan gips dengan satu atau lebih lempung organik, atau hasil pencampuran antara bubuk semen Portland dengan bubuk anorganik lain [9]. Semen Portland komposit merupakan varian jenis baru yang telah dikembangkan dan di produksi secara massal oleh pabrik semen yang sebagai produsen semen dengan cara memberikan bahan tambahan (inert) dari semen Portland tipe I. Semen Portland composite yang di pakai dalam pembuatan betonnya yaitu harus semen yang berbutir halus. Kehalusan dari semen ini dapat di raba / di rasakan secara visual dengan tangan. Nilai FAS 0,4 memiliki nilai kuat tekan yang lebih tinggi dari pada beton yang menggunakan FAS 0,5 dan 0,6 [10].

b. Air merupakan salah satu faktor penting dalam penggunaan beton, karena akan bereaksi dengan semua material penyusun beton, khususnya semen yang akan menjadi pasta pengikat agregat. Air akan sangat berpengaruh terhadap hasil nilai kuat tekan desak beton, karena jika kekurangan air maka ikatan antar material menjadi kurang baik. Di samping itu, kelebihan air juga akan menurunkan kualitas kuat desak beton itu sendiri, hal ini akan menyebabkan beton menjadi bleeding. Hal ini dapat menciptakan terjadinya pemisahan antara material, dimana air dan semen akan naik ke permukaan dan agregat kasar akan turun ke bawah. Menurut Peraturan Beton Bertulang Indonesia Tahun 1971 (PBI-1971) [11], air yang digunakan untuk pembuatan dan perawatan beton tersebut harus tidak boleh mengandung minyak, asam, alkali, garam-garam, bahan ke bawah organik atau bahan-bahan lain yang dapat merusak beton dan atau baja tulangan.

c. Agregat halus (pasir sungai) adalah agregat terdiri dari butiran material alami maupun buatan yang berfungsi sebagai bahan pengisi dalam campuran beton. Agregat sangat berpengaruh terhadap kualitas 
mutu dari suatu beton tersebut. Dalam penelitian ini agregat halus, harus benar C. memenuhi persyaratan yang di tentukan [12]. Agregat halus harus di uji sifat fisiknya [13].

d. Agregat Kasar (Batu Pecah Sungai) merupakan salah satu bahan utama dalam pembuatan beton. Agregat kasar yang biasanya disebut kerikil bisa berasal alami dari alam dan buatan yang berfungsi sebagai pengisi dari volume beton.

\section{Karakteristik Beton}

a. Kuat Tekan Beton

Kuat tekan beton merupakan besarnya pembacaan nilai beban pada alat uji per satuan luas, sehingga menyebabkan benda uji beton hancur saat dibebani gaya tekan dari mesin uji tekan.

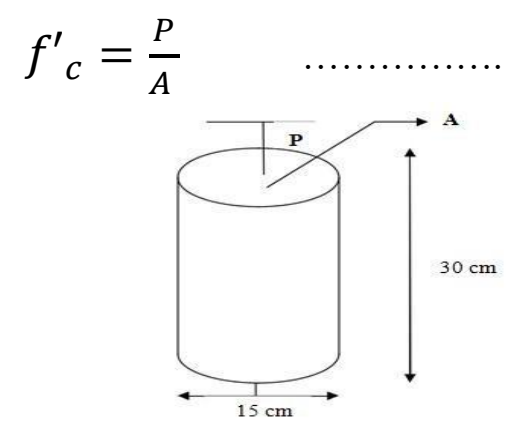

\section{b. Kuat Tarik Belah Beton}

\section{Gambar 1 Uji Kuat Tekan}

Kuat tarik belah adalah kuat tarik belah beton yang diperoleh berdasarkan beban yang mampu diterima beton pada sisi panjangnya sampai terjadi belah pada beton.

$$
f^{\prime}{ }_{c t}=\frac{2 P}{\pi L D}
$$
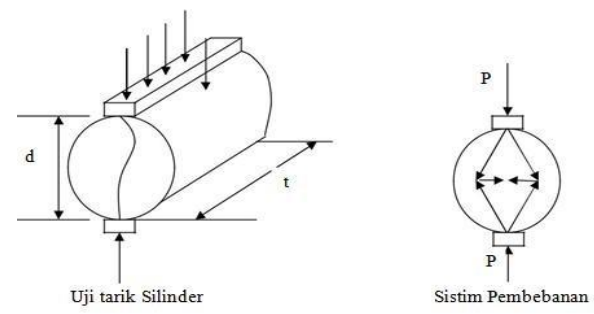

Gambar 2 Uji Kuat Tarik Belah

\section{c. Kuat Lentur Beton}

Kuat lentur beton adalah kemampuan balok beton untuk menahan gaya dengan arah tegak lurus sumbu yang diberikan padanya sampai balok beton patah dan dinyatakan dalam Mega Pascal (MPa). Kuat lentur beton dihitung dengan menggunakan Persamaan (3), dengan mekanisme pengujian yang ditunjukkan pada Gambar 3.

$$
f^{\prime}{ }_{c}=\frac{P L}{b h^{2}}
$$




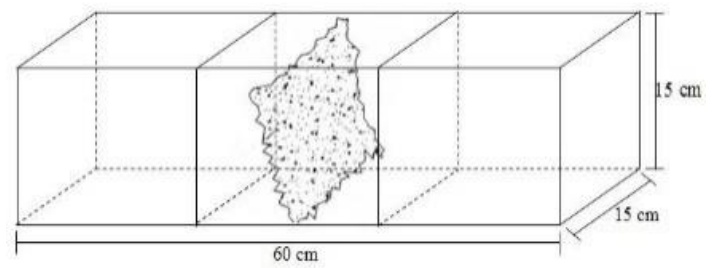

Gambar 3 Uji Kuat Lentur

Apabila keruntuhan terjadi pada bagian tarik di luar tengah bentang (Gambar 4), maka digunakan persamaan (4).

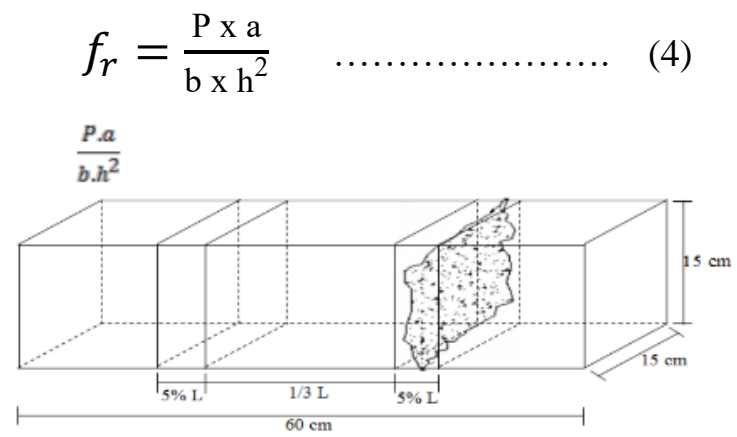

Gambar 4 Uji Kuat Lentur

Namun untuk benda uji yang patahnya di luar pusat (daerah jarak 1/3 titik perletakan bagian tengah) dan jarak antara titik pembebanan dan titik patah lebih dari $5 \%$ bentang,

\section{d. Modulus Elastisitas}

Modulus elastisitas dapat ditentukan dari perbandingan antara tegangan terhadap regangan dalam batas elastisnya. Modulus juga merupakan salah satu kekuatan mekanik dari suatu beton yang sangat penting.

$$
E c=\frac{\mathrm{S} 2-\mathrm{S} 1}{\varepsilon 2-0,00005}
$$

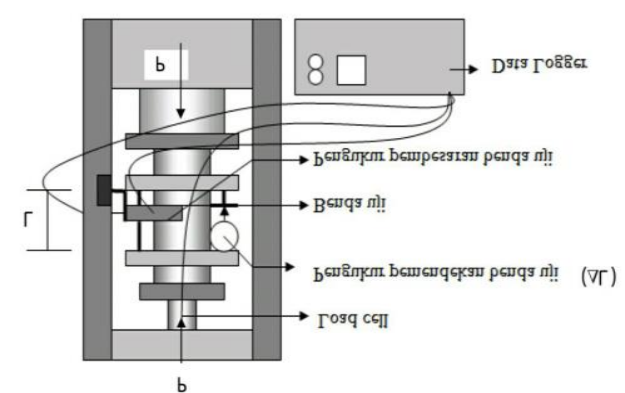

Gambar 5 Uji Modulus Elastisitas 


\section{METODOLOGI}

Lokasi pengambilan material berada di sungai To Puang, Kabupaten Tana Toraja.

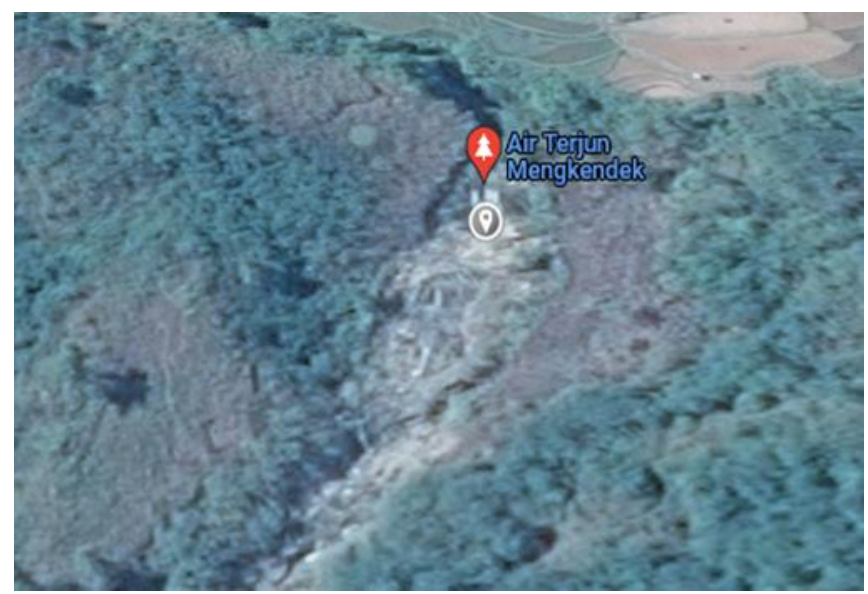

Gambar 6. Lokasi Pengambilan Sampel

\section{Pemeriksaan Karakteristik Agregat}

Pemeriksaan karakteristik agregat halus mengacu pada spesifikasi Standar Nasional Indonesia agregat halus haruslah butir-butir yang keras dan tajam, dan tidak mudah hancur. Agregat kasar dan halus yang digunakan untuk campuran, termasuk juga akibat perubahan seperti sinar matahari dan hujan, tidak boleh mengandung lumpur. Beton adalah material yang di nilai lebih praktis dan ekonomis dibanding material lain [14].

Tabel 1 Tabel Standar Pengujian Karakteristik Agregat Halus

\begin{tabular}{cccc}
\hline No & Nama Percobaan & Interval & Standar Rujukan \\
\hline 1 & Kadar Air, $\%$ & $3-5$ & SNI 1971 - 2011 \\
\hline 2 & Berat Volume, $\mathrm{kg} / \mathrm{m}^{3}$ & $1400-1900$ & SNI 03 - 4804 - 1998 \\
\hline 3 & Kadar Lumpur, $\%$ & $0,2-6$ & SNI 03 - 4428 - 1996 \\
\hline 4 & Penyerapan, $\%$ & $0,2-2$ & SNI 1970 - 2008 \\
\hline 5 & Berat Jenis, (SSD) & $1,6-3,2$ & SNI 1970 - 2008 \\
\hline 6 & Modulus Kehalusan & $2,20-3,10$ & SNI 03 - 1698 - 1990 \\
\hline 7 & Kadar Organik & $<$ No. 3 & SNI 2816 - 2014 \\
\hline
\end{tabular}

Tabel 2 Tabel Standar Pengujian Karakteristik Agregat Kasar

\begin{tabular}{cccc}
\hline No & Nama Percobaan & Interval & Standar Rujukan \\
\hline 1 & Kadar Air, $\%$ & $0-2,0$ & SNI $1971-2011$ \\
\hline 2 & Berat Volume, $\mathrm{kg} / \mathrm{m}^{3}$ & $1400-1900$ & SNI 03 - 4804 - 1998 \\
\hline 3 & Kadar Lumpur, $\%$ & $0,2-6$ & SNI 03 - 4428 - 1996 \\
\hline 4 & Penyerapan, $\%$ & $0,2-2$ & SNI $1970-2008$ \\
\hline 5 & Berat Jenis, (SSD) & $1,6-3,2$ & SNI $1970-2008$ \\
\hline 6 & Kadar Lumpur & $0,2-1,0$ & SNI 2816 - 2014 \\
\hline
\end{tabular}


Volume 3 Issue 4, Desember 2021

\section{Identifikasi Benda Uji}

Tabel 3 Tabel Identifikasi Untuk Pengujian

\begin{tabular}{|c|c|c|c|c|c|}
\hline Kode & Jenis Pengujian & $\begin{array}{l}\text { Umur Benda } \\
\text { Uji }\end{array}$ & $\begin{array}{c}\text { Bentuk Benda Uji } \\
(\mathrm{mm})\end{array}$ & $\begin{array}{c}\text { Jumlah } \\
\text { Benda Uji }\end{array}$ & $\begin{array}{c}\text { Kuat Tekan } \\
\text { Rencana (MPa) }\end{array}$ \\
\hline \multirow{3}{*}{ KTB } & \multirow{3}{*}{ Kuat Tekan Beton } & 7 Hari & \multirow{3}{*}{ Silinder 150 x 300} & 3 & 28 \\
\hline & & 21 Hari & & 3 & 28 \\
\hline & & 28 Hari & & 3 & 28 \\
\hline TBB & Tarik Belah Beton & 28 Hari & Silinder 150 × 300 & 3 & 28 \\
\hline KLB & Lentur Balok Beton & 28 Hari & Balok $600 \times 150 \times 150$ & 3 & 28 \\
\hline MEB & Modulus Elastisitas & 28 Hari & Silinder $300 \times 150$ & 3 & 28 \\
\hline
\end{tabular}

\section{Hasil Pemeriksaan Karakteristik Agregat Kasar.}

Agregat kasar merupakan salah satu bahan utama dalam pembuatan beton. Agregat kasar yang berfungsi sebagai pengisi dari volume beton. Menurut SNI 03 - 2847 - 2002, Agregat kasar merupakan agregat yang mempunyai ukuran butir antara 5,00 $\mathrm{mm}$ sampai $40 \mathrm{~mm}$ [15]. Proses pencucian agregat beton untuk struktur maupun non struktur harus dilakukan jika mengandung kadar lumpur yang tinggi.

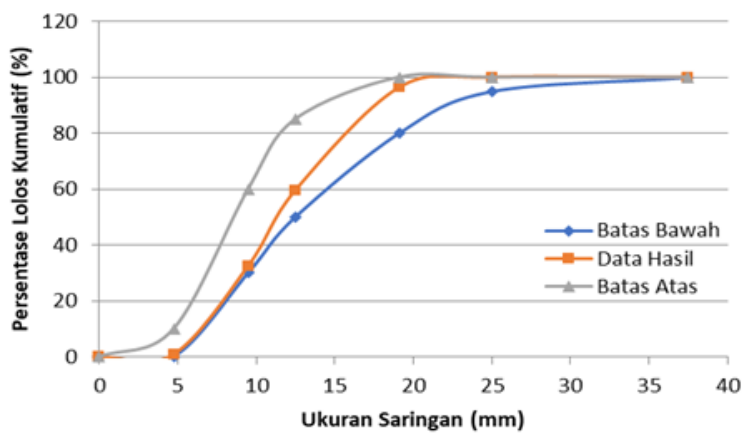

Gambar 7 Grafik Analisa Saringan Agregat Kasar

Tabel 4 Tabel Hasil Pengujian Agregat Kasar

\begin{tabular}{clccl}
\hline No. & Karakteristik Agregat Kasar & Hasil & Interval SNI & Keterangan \\
\hline 1 & Kadar Lumpur, \% & 0,440 & $0,2-1,00$ & Memenuhi \\
\hline 2 & Kadar Air, $\%$ & 0,528 & $0,50-2,00$ & Memenuhi \\
\hline 3 & Berat Volume Padat, $\mathrm{kg} / \mathrm{m}^{3}$ & 1532,199 & $1400-1900$ & Memenuhi \\
\hline 4 & Berat Volume Gembur, $\mathrm{kg} / \mathrm{m}^{3}$ & 1484,001 & $1400-1900$ & Memenuhi \\
\hline 5 & Penyerapan, \% & 0,442 & $0,20-2,00$ & Memenuhi \\
\hline 6 & Berat Jenis, SSD & 2,753 & $1,60-3,20$ & Memenuhi \\
\hline
\end{tabular}

\section{Hasil Pemeriksaan Karakteristik Agregat Halus}

Agregat halus adalah agregat yang mempunyai ukuran berkisar antara $1 \mathrm{~mm}-4,75 \mathrm{~mm}$. Agregat halus yang digunakan harus yang berasal dari perairan tawar, tidak boleh digunakan pasir laut (kecuali dengan ijin staf ahli), tidak boleh mengandung lumpur karena lumpur akan mempengaruhi ikatan antar agregat. 


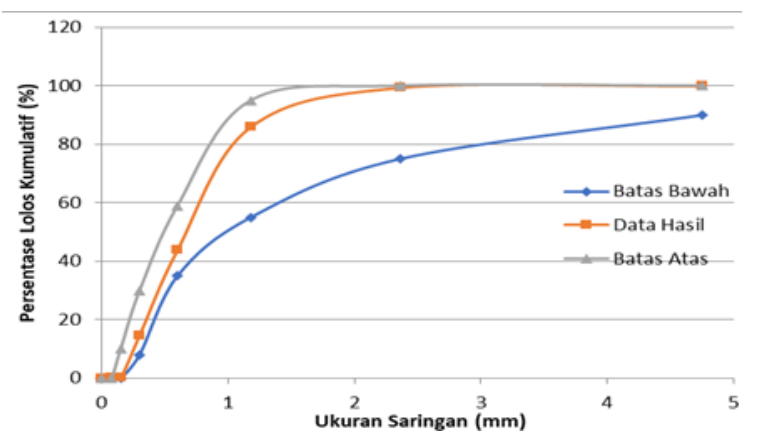

Gambar 8 Grafik Analisa Saringan Agregat Halus

Tabel 5 Tabel Hasil Pengujian Agregat Halus

\begin{tabular}{clccl}
\hline No. & Karakteristik Agregat Halus & Hasil & Interval SNI & Keterangan \\
\hline 1 & Kadar Lumpur, \% & 2,80 & $0,2-6$ & Memenuhi \\
\hline 2 & Kadar Organik, Warna & $<3$ & $<$ No.3 & Memenuhi \\
\hline 3 & Kadar Air, \% & 3,119 & $3,0-5,0$ & Memenuhi \\
\hline 4 & Berat Volume Padat, kg/ltr & 1446,67 & $1400-1900$ & Memenuhi \\
\hline 5 & Berat Volume Gembur, kg/ltr & 1411,67 & $1400-1900$ & Memenuhi \\
\hline 6 & Penyerapan, \% & 1,938 & $0,20-2,00$ & Memenuhi \\
\hline 7 & Berat Jenis, SSD & 2,457 & $1,6-3,2$ & Memenuhi \\
\hline 8 & Modulus Kehalusan & 2,551 & $2,20-3,10$ & Memenuhi \\
\hline
\end{tabular}

\section{Perhitungan Komposisi Mix Design Beton}

Perhitungan komposisi campuran untuk pembuatan benda uji mengacu pada Mix Design menggunakan metode SNI 7656 - 2012. Berbeda dengan metode SNI 032834 - 2000 yang proses mix design menggunakan tabel dan grafik, metode SNI 7656 - 2012 ini hanya menggunakan tabel tanpa grafik yang digunakan dalam mencari besarnya komposisi campuran [16]. Kuat tekan rencana (f'c) yaitu 28 Mpa. Slump test yang digunakan adalah $75-100 \mathrm{~mm}$. Hasil perhitungan mix design dapat dilihat pada table pada tabel 6 yang dilampirkan.

Tabel 6 Tabel Hasil Perhitungan Mix Design

\begin{tabular}{cl}
\hline Material & Berat \\
\hline Air & $193 \mathrm{~kg} / \mathrm{m}^{3}$ \\
\hline Semen & $439 \mathrm{~kg} / \mathrm{m}^{3}$ \\
\hline Pasir (Agregat Halus) & $654 \mathrm{~kg} / \mathrm{m}^{3}$ \\
\hline Kerikil (Agregat Kasar) & $1065 \mathrm{~kg} / \mathrm{m}^{3}$ \\
\hline
\end{tabular}




\section{ANALISA DAN PEMBAHASAN}

\section{Kuat Tekan}

Uji kuat tekan sesuai dengan SNI 1974 - 2014 [17], bertujuan untuk mengetahui kekuatan beton dalam menerima beban tekan dalam satuan $\mathrm{kN}$. Setelah mencapai umur rencana perawatan 7, 21, dan 28 hari. Setiap benda uji, di uji menggunakan Compression Testing Machine untuk mendapatkan beban maksimum dimana beban pada saat beton hancur. Pada umur 28 hari kekuatan beton telah mencapai $100 \%$.

Tabel 7 Tabel Hasil Pengujian Kuat Tekan

\begin{tabular}{|c|c|c|c|c|c|c|c|}
\hline Umur & $\begin{array}{c}\text { Berat } \\
(\mathrm{kg})\end{array}$ & $\begin{array}{c}\text { Beban } \\
\text { Maks } \\
(\mathrm{kN})\end{array}$ & $\begin{array}{c}\text { Kuat Tekan } \\
\text { Aktual } \\
(\mathrm{MPa})\end{array}$ & $\begin{array}{c}\text { Rata-Rata } \\
\text { Kuat Tekan } \\
\text { Aktual (MPa) }\end{array}$ & $\begin{array}{c}\text { Kuat } \\
\text { Tekan } 28 \\
\text { hari (MPa) }\end{array}$ & $\begin{array}{c}\text { Rata-Rata } \\
\text { Kuat Tekan } \\
28 \text { hari }(\mathrm{MPa})\end{array}$ & $\begin{array}{c}\text { Berat Volume } \\
\text { Beton } \\
\left(\mathrm{kg} / \mathrm{m}^{3}\right)\end{array}$ \\
\hline \multirow{3}{*}{7 hari } & 12,52 & 345 & 19,533 & \multirow{3}{*}{19,344} & 30,051 & \multirow{3}{*}{29,760} & 2362,264 \\
\hline & 12,44 & 350 & 19,816 & & 30,486 & & 2347,170 \\
\hline & 12,33 & 330 & 18,684 & & 28,744 & & 2326,415 \\
\hline \multirow{3}{*}{21 hari } & 12,80 & 505 & 28,592 & \multirow{3}{*}{28,686} & 30,096 & \multirow{3}{*}{30,196} & 2415,094 \\
\hline & 12,88 & 515 & 29,158 & & 30,692 & & 2430,189 \\
\hline & 12,56 & 500 & 28,309 & & 29,798 & & 2369,811 \\
\hline \multirow{3}{*}{28 hari } & 12,94 & 545 & 30,856 & \multirow{3}{*}{30,384} & 30,856 & \multirow{3}{*}{30,384} & 2441,509 \\
\hline & 12,76 & 530 & 30,007 & & 30,007 & & 2407,547 \\
\hline & 12,82 & 535 & 30,290 & & 30,290 & & 2418,868 \\
\hline
\end{tabular}

\section{Kuat Tarik Belah}

Uji kuat tarik belah beton sesuai dengan SNI 2491 - 2014 [18] bertujuan untuk mengetahui besarnya gaya tarik belah maksimal yang diberikan kepada beton dalam satuan $\mathrm{kN}$. Setelah mencapai umur rencana perawatan benda uji 28 hari, nilai dari kuat tarik belah beton telah mencapai $100 \%$.

Tabel 8 Tabel Hasil Pengujian Kuat Tarik Belah

$\begin{array}{ccc}\text { Umur } & \text { Beban Maks }(\mathrm{kN}) \quad \text { Kuat Tarik Belah }(\mathrm{Mpa}) \quad \begin{array}{c}\text { Rata Rata Kuat Tarik } \\ \text { Belah }(\mathrm{MPa})\end{array}\end{array}$

\begin{tabular}{lll} 
& 200 & 2,831 \\
\cline { 2 - 3 } 28 Hari & 195 & 2,760
\end{tabular}$\quad 2,902$

\section{Kuat Lentur}

Prosedur pengujian kuat lentur mengacu pada SNI 4431 - 2011 [19], dimana kemampuan balok beton yang di letakkan pada arah tegak lurus sumbu benda uji yang diberikan kepadanya, sampai benda uji patah, yang dinyatakan dalam satuan Mega Pascal (MPa) per satuan luas. Setelah umur rencana mencapai 28 hari, maka dilakukan proses pengujian kuat lentur di laboratorium. Kuat lentur balok mempunyai kekuatan $11 \%-23 \%$ dari kuat tekan beton.

Tabel 9 Tabel Hasil Pengujian Kuat Lentur

\begin{tabular}{cccc}
\hline Umur & Beban Maks (Ton) & $\begin{array}{c}\text { Kuat Tarik Lentur } \\
(\mathrm{Mpa})\end{array}$ & $\begin{array}{c}\text { Rata Map kuat } \\
\text { Lentur (MPa) }\end{array}$ \\
\hline
\end{tabular}




\begin{tabular}{|c|c|c|c|}
\hline \multirow{3}{*}{28 hari } & 2,1 & 3,174 & \multirow{3}{*}{3,376} \\
\hline & 2,4 & 3,628 & \\
\hline & 2,2 & 3,325 & \\
\hline
\end{tabular}

\section{Modulus Elastisitas}

Prosedur pengujian dilaksanakan berdasarkan ASTM C 469 - 02, dimana pengujian modulus ini dilakukan pada umur beton 28 hari.

Berdasarkan SNI 2847: 2013 pasal 8.5.1. Modulus beton teoritis diambil sebesar $\mathrm{E}_{\mathrm{c}} 4700 \sqrt{f^{\prime} c}$.

Tabel 10 Tabel Hasil Pengujian Modulus Elastisitas

\begin{tabular}{cccc}
\hline Umur & Ukuran Benda Uji (mm) & $\begin{array}{c}\text { Kuat Tarik Belah } \\
\text { Aktual (Mpa) }\end{array}$ & $\begin{array}{c}\text { Rata Rata Kuat Tarik } \\
\text { Belah Aktual (Mpa) }\end{array}$ \\
\hline \multirow{2}{*}{28 hari } & Silinder $150 \times 300$ & 20419,357 & \multirow{2}{2}{20820,747} \\
\cline { 2 - 3 } & $\frac{22631,297}{19411,586}$ & \\
\hline
\end{tabular}

\section{KESIMPULAN}

Dari hasil perhitungan mix design menggunakan metode SNI 7656: 2012 diperoleh hasil komposisi campuran beton yang menggunakan agregat dari Sungai To Puang Kabupaten Tana Toraja untuk $28 \mathrm{MPa}$ adalah air $193 \mathrm{~kg} / \mathrm{m} 3$, semen $439 \mathrm{~kg} / \mathrm{m} 3$, pasir $654 \mathrm{~kg} / \mathrm{m} 3$, kerikil $1065 \mathrm{~kg} / \mathrm{m} 3$ dengan persentase perbandingan komposisi sebesar Air: Semen: Pasir: Kerikil atau 8,209 \%: 18,673 \%: 27,818 \%: 45,3 \%.

Dari hasil penelitian diperoleh nilai kuat tekan pada umur 28 hari sebesar 30,290 MPa mengalami kenaikan sebesar 8,176 \%, nilai kuat tarik belah sebesar 2,902 MPa, nilai kuat lentur 3,376 MPa, dan nilai modulus elastisitas 20820,747 MPa. Agregat dari sungai ini dapat digunakan dalam pembuatan campuran normal.

\section{DAFTAR PUSTAKA}

[1] S. B. Ahmad, "Investigasi Pengaruh Air Laut Sebagai Air Pencampuran Dan Perawatan Terhadap Sifat Beton," Journal INTEK, vol. 5, no. 1, pp. 48-52, 2018.

[2] S. Arian, Roestaman and S. Permana, "Pengrauh Penggunaan Agregat Kasar Kerikil Alami Terhadap Mutu Beton," Jurnal Konstruksi, vol. 19, no. 1, pp. 52-59, 2021.

[3] M. Y. Mau, E. Hunggurami and T. M. W. Sir, "Kuat Tekan Beton Menggunakan Agregat Halus Sungai Benlelang Dan Sungai Lembur Serta Agregat Kasar Sungai Lembur," Jurnal Teknik Sipil, vol. VII, no. 1, pp. 31 36, 2018.

[4] R. Amelia, S. Suhendra and K. R. Amalia, "Hubungan Faktor-Faktor yang Mempengaruhi Kuat Tekan Beton," Jurnal Talenta Sipil, vol. 4, no. 2, pp. 225-235, 2021.

[5] M. B. Masgode and Imran, "Analisis Kuat Tekan Beton Normal Dengan Menggunakan Pasir Sungai Ulu LapaoPao," DINTEK, vol. 14, no. 2, pp. 26-33, 2021.

[6] R. Komala, S. Hadi and J. Prasetiawan, "Pengaruh Jenis Semen Dan Lama Perawatan Yang Berbeda Terhadap Kuat Tekan Beton Normal," Jurnal Andasah, vol. 1, no. 2, 2021.

[7] S. Latjemma, "Pengaruh Sumber Material Agregat Halus Sebagai Bahan Campuran Terhadap Kuat Tekan Beton Normal," Media Bina Ilmiah, vol. 16, no. 1, pp. 6035-6048, 2021. 
[8] C. Kamba, "Agregat dari Material Lokal," dalam Pemanfaatan Material Alternatif (Sebagai Bahan Penyusun Konstruksi), Makassar: CV. Tohar Media, 2021, hlm. 35-46.

[9] SNI 15-7064-2004, Semen Portland Komposit, Jakarta: Badan Standardisasi Indonesia, 2004.

[10] R. A. I. Sari, S. E. Wallah and R. S. Windah, "Pengaruh Jumlah Semen Dan Fas Terhadap Kuat Tekan Beton Dengan Agregat Yang Berasal Dari Sungai," Jurnal Sipil Statik, vol. 3, no. 1, pp. 68-76, 2015.

[11] PBI 1971, "Peraturan Beton Indonesia," Dapartemen Pekerjaan Umum, 1971.

[12] I. M. S. Wibawa, I. G. A. Diputera and I. K. D. K. Tubuh, "Kuat Tekan Beton Yang Terjadi Akibat Penggunaan Pecahan Genteng Darmasaba Sebagai Pengganti Sebagian Agregat Kasar," Jurnal Ilmiah Kurva Teknik, vol. 10, no. 1, pp. 33-41, 2021.

[13] Z. A. Pertiwi, A. Suryadi and A.Sugiarto, "Analisis Karakteristik Beton Normal Dengan Batu Karang Gunung Madura Sebagai Substitusi Kerikil," Jurnal Online Skripsi, vol. 4, no. 2, pp. 267-272, 2021.

[14] M. Irwansyah, "Pengaruh Pemakaian Abu Sekam Padi Menggunakan Agregat Lokal Terhadap Kekuatan beton Normal (Agregat Kasar Desa Maranji Aceh kecamatan Aek Songsongan, Agregat Halus Desa Tanjung Alam Kecamatan Sei Dadap)," Jurnal Pionir, vol. 7, no. 2, pp. 130-138, 2021.

[15] SNI 03-2847-2002, Tata Cara Pembuatan Campuran Beton Normal, Bandung: Badan Standardisasi Nasional, 2002.

[16] Tavio and T. H. Bagio, Dasar-Dasar Beton Bertulang, Surabaya: Andi publisher, 2020.

[17] SNI 1974-2014, Cara Uji Kuat Tekan Beton Dengan Benda Uji Silinder, Jakarta: BSN, 2014.

[18] SNI 2491-2014, Metode Uji Kekuatan Tarik Belah Spesimen Beton Silinder, Badan Standardidasi Nasional, 2014. 